Artikel Penelitian

\title{
Adsorpsi Logam Ni dan Cu pada Limbah Cair Laboratorium Kimia menggunakan Biosorben Batang Jagung Termodifikasi Asam Sitrat
}

\author{
Eny Yulianti', Rifatul Mahmudah, Ainul Ma'rifah, Ulal Azmiyani
}

Jurusan Kimia, Fakultas Sains dan Teknologi, Universitas Islam Negeri Maulana Malik Ibrahim, Malang, Indonesia, 65144

INFO ARTIKEL

Riwayat Artikel

Diterima 2 April 2019

Direvisi 6 Mei 2019

Tersedia online 28 Agustus 2019

*Email penulis korespondensi:

enyyulianty@kim.uin-malang.ac.id

\section{ABSTRAK}

Corn stalk contains $40-50 \%$ cellulose, $20-40 \%$ hemicellulose, $4-15 \%$ lignin which had potential as biosorbent in binding metal ions. In this study, demineralization and modification by adding citric acid (1.5 $\mathrm{M}$ and $2 \mathrm{M}$ ) of corn stalk were conducted to convert hydroxyl groups into carboxylic. Then, it was analyzed its functional groups using Boehm titration and FTIR. The modified corn stalk was applied directly to chemical laboratory liquid waste which contains multicomponent of heavy metal ions. By modifying the corn stalk, the number of hydroxyl and carboxylic groups increased, but the number of lactone group was constant. The success of the modification was characterized by the appearance of ester uptake at $1734 \mathrm{~cm}^{-1}$ and increased adsorption ability. The variations in the concentration of citric acid in modification corn stalk showed that biosorbent with addition $1.5 \mathrm{M}$ citric acid had higher in the number of acid site than addition $2 \mathrm{M}$ citric acid to absorb $\mathrm{Ni}$ and $\mathrm{Cu}$.

Keywords: Corn stalk, citric acid, biosorbent, functional group

Batang jagung mengandung sekitar $40-50 \%$ selulosa, $20-40 \%$ hemiselulosa, 4$15 \%$ lignin yang berpotensi sebagai biosorben pengikat ion logam. Pada penelitian ini dilakukan demineralisasi dan modifikasi dengan penambahan asam sitrat (1,5 M dan $2 \mathrm{M}$ ) untuk mengubah gugus hidroksil pada selulosa membentuk karboksilat. Selanjutnya, dianalisis gugus fungsinya menggunakan titrasi Boehm dan FTIR. Hasil modifikasi diaplikasikan langsung pada limbah cair laboratorium kimia yang mengandung banyak jenis ion logam berat. Biosorben batang jagung setelah dimodifikasi mengalami peningkatan jumlah gugus fungsi hidroksil dan karboksilat, tetapi gugus lakton tetap. Keberhasilan modifikasi ditandai dengan munculnya serapan ester pada $1734 \mathrm{~cm}^{-1}$ dan peningkatan kemampuan adsorpsi. Dari hasil variasi konsentrasi asam sitrat diperoleh informasi bahwa biosorben dengan penambahan asam sitrat 1,5 $\mathrm{M}$ mempunyai situs asam lebih tinggi dan mempunyai kemampuan adsorpsi terhadap ion logam $\mathrm{Ni}$ dan $\mathrm{Cu}$ lebih besar dibanding penambahan asam sitrat $2 \mathrm{M}$.

Kata kunci: Batang jagung, asam sitrat, biosorben, gugus fungsi 


\section{Pendahuluan}

Logam berat dikenal sangat reaktif, beracun dan mempunyai mobilitas tinggi di dalam air. Logam berat sangat berbahaya bagi lingkungan dan kesehatan. Konsentrasi tinggi logam berat secara alami ditemukan di batuan. Namun, semakin tingginya aktivitas berbagai industri yang menggunakannya menjadikan logam berat banyak tersebar di lingkungan. Modifikasi biopolimer (seperti turunan dari kitin, kitosan dan selulosa) menghasilkan biosorben dengan kapasitas adsorpsi yang tinggi untuk limbah logam berat, fenol, cat dan polutan organik lainnya. Kelebihan lain dari biosorben ini adalah relatif mudah dibuat dan murah [1, 2, 3, 4].

Selama tahun 2015, Badan Pusat Statistik (BPS) Indonesia memaparkan bahwa produksi tanaman jagung Indonesia mencapai 19,03 juta ton [5]. Batang jagung adalah produk samping terbesar dalam produksi jagung. Batang jagung mengandung selulosa, hemiselulosa dan lignin $[6,7]$. Komposisi selulosa, hemiselulosa dan lignin pada batang jagung masing-masing berkisar 36,9-41,43; 21,77-37,30 dan 3,38-7,52\% [8]. Hal ini menginformasikan bahwa batang jagung sangat berpotensi sebagai bahan baku biosorben yang melimpah, ramah lingkungan dan murah [9]. Beberapa penelitian mempelajari kemampuan adsorpsi batang jagung alami pada logam berat. Hasilnya adalah kapasitas adsorpsi batang jagung alami tanpa modifikasi sangat rendah dibanding adsorben tradisonal lainnya seperti zeolite alami. Hal ini karena batang jagung terdiri dari lignin, hemiselulosa dan polisakarida selulosa. Sementara itu, adsorpsi logam hanya terjadi pada grup gugus hidroksilik dari selulosa dan fenolik, serta hidroksilik dan karboksilik dari lignin [10].

Kapasitas adsorpsi dapat ditingkatkan dengan meningkatkan situs adsorpsi melalui modifikasi gugus fungsi [11]. Komponen utama batang jagung adalah selulosa yang kaya akan gugus hidroksil dan gugus inilah yang berpotensi utama untuk dilakukan modifikasi melalui reaksi kimia $[2,10,12,13,14]$. Beberapa bahan kimia digunakan untuk memodifikasi limbah jagung dan terbukti dapat meningkatkan kapasitas adsorpsi, seperti akrilonitril [2], asam sitrat [10] dan asam nitrat [14].

Pada penelitian ini digunakan asam sitrat karena tergolong asam karboksilat dan asam lemah yang lebih ramah lingkungan dan relatif lebih murah dibandingkan beberapa bahan kimia lainnya seperti $\mathrm{HCl}, \mathrm{H}_{2} \mathrm{SO}_{4}$ dan $\mathrm{HNO}_{3}$. Batang jagung didemineralisasi menggunakan $\mathrm{HCl}$ dan dilanjutkan dengan modifikasi menggunakan asam sitrat, kemampuan adsorpsinya diujikan dalam penurunan Ni dan Cu pada limbah cair Laboratorium Kimia UIN Malang yang mengandung banyak jenis ion logam berat. Karakterisasi yang dilakukan meliputi analisis kualitatif gugus fungsi menggunakan FTIR (Fourier Transform Infrared), analisis kuantitatif kadar karboksilat, hidroksil dan lakton menggunakan titrasi Boehm, serta analisis kadar logam menggunakan AAS (Atomic Absorption Spectoscopy).

\section{Bahan dan Metode}

\subsection{Bahan}

Bahan utama adalah batang jagung dari Desa Poncokusumo, Kabupaten Malang. Bahan lain yang digunakan meliputi akuades, $\mathrm{NaOH} 98 \%$ (Merck), asam sitrat 99,5\% (Merck), $\mathrm{HCl} 37 \%$ (Merck), $\mathrm{HNO}_{3} 65 \%$ (Merck), $\mathrm{NaHCO}_{3}$ (Merck), $\mathrm{Na}_{2} \mathrm{CO}_{3}$ (Merck), $\mathrm{AgNO}_{3}$ (Merck), indikator fenolftalein, indikator metil merah, dan limbah cair golongan logam berat laboratorium Kimia UIN Maulana Malik Ibrahim Malang.

\subsection{Pembuatan Biosorben}

Preparasi sampel yaitu batang jagung kering dicuci bersih, dipotong kecil-kecil, kemudian dikeringkan di bawah sinar matahari hingga batang jagung mengering. Sampel yang sudah kering kemudian digiling hingga halus. Serbuk batang jagung diambil 35 gram dan direndam dalam $700 \mathrm{~mL}$ larutan $\mathrm{HCl}$ 0,1 M (demineralisasi) sampai terbentuk pasta. Kemudian dishaker dengan kecepatan 100 rpm selama 30 menit. Selanjutnya, disaring dengan kertas saring, dicuci dengan aquades hingga biomassa bebas ion $\mathrm{Cl}$. Filtrat diuji dengan larutan $\mathrm{AgNO}_{3}$ dan sisa ion $\mathrm{Cl}$ yang terkandung sudah hilang bila sudah tidak terbentuk endapan putih. Kemudian padatan dikeringkan dalam oven dengan suhu $60^{\circ} \mathrm{C}$ selama 5 jam dan diulangi sampai berat konstan dan disimpan dalam desikator pada saat pendinginan.

Modifikasi biosorben menggunakan asam sitrat. Sebanyak 5 gram serbuk batang jagung direndam dalam $100 \mathrm{~mL}$ larutan asam sitrat dengan variasi konsentrasi $1,5 \mathrm{M}$ dan $2 \mathrm{M}$. Kemudian masing-masing variasi dipanaskan selama 2 jam dengan suhu $60^{\circ} \mathrm{C}$, didinginkan dan dipisahkan dari serbuk batang jagung. Kemudian dikeringkan dalam oven pada suhu $50^{\circ} \mathrm{C}$ selama 24 jam dan dinaikkan sampai $120^{\circ} \mathrm{C}$ selama 3 jam dan dibiarkan dingin. Serbuk batang jagung dicuci menggunakan akuades hingga $\mathrm{pH}$ netral. Serbuk batang jagung dikeringkan dalam oven pada suhu $50^{\circ} \mathrm{C}$ selama 24 jam. Pada proses ini diperoleh 4 variasi adsorben, yaitu batang jagung alami (BA), batang jagung hasil demineralisai (AKT), batang jagung modifikasi asam sitrat 1,5 M (AM 1,5 M), dan batang jagung modifikasi asam sitrat $2 \mathrm{M}(\mathrm{AM} 2 \mathrm{M})[2,4,10$, $15]$. 


\subsection{Penentuan Konsentrasi Gugus Aktif Batang Jagung melalui Titrasi Boehm}

Konsentrasi sifat asam batang jagung sebelum dan setelah termodifikasi ditentukan menggunakan metode Boehm $[16,17,18]$. Pada semua varian adsorben, masing-masing dilakukan perendaman sebanyak 0,25 gram serbuk ke dalam $25 \mathrm{~mL}$ reagen yang berbeda yaitu $\mathrm{NaHCO}_{3} 0,05 \mathrm{~N}, \mathrm{Na}_{2} \mathrm{CO}_{3} 0,05 \mathrm{~N}$, dan $\mathrm{NaOH} 0,05 \mathrm{~N}$. Campuran didiamkan selama 24 jam dengan sesekali diaduk manual, setelah itu disaring menggunakan kertas saring. Sebanyak $10 \mathrm{~mL}$ masing-masing filtrat dipipet dan dimasukkan ke dalam erlenmeyer, kemudian ditambahkan $20 \mathrm{~mL}$ larutan $\mathrm{HCl} 0,05 \mathrm{~N}$. Kemudian ditambahkan 2-3 tetes indikator fenolftalein. Analit tersebut dititrasi balik menggunakan $\mathrm{NaOH} \mathrm{0,05} \mathrm{N}$. Semua perlakuan dilakukan tiga kali ulangan. Penentuan konsentrasi gugus fungsi karboksil menggunakan Persamaan (1), konsentrasi gugus fungsi karboksil dan lakton menggunakan Persamaan (2), dan jumlah gugus lakton menggunakan Persamaan (3).

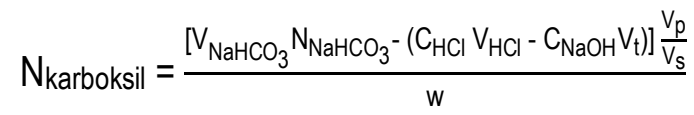

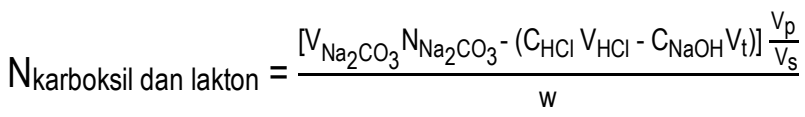

$$
\begin{aligned}
& \text { Jumlah gugus lakton }=\mathrm{N}_{\text {karboksil }}-\mathrm{N}_{\text {karboksil dan lakton }}
\end{aligned}
$$

Penentuan konsentrasi gugus fungsi hidroksil menggunakan Persamaan (4) dan (5).

$$
\begin{gathered}
N_{\text {hidroksil }}=\frac{\left[\mathrm{V}_{\mathrm{NaOH}} \mathrm{N}_{\mathrm{NaOH}}-\left(\mathrm{C}_{\mathrm{HCl}} \mathrm{V}_{\mathrm{HCl}}-\mathrm{C}_{\mathrm{NaOH}} \mathrm{V}_{\mathrm{t}}\right)\right] \frac{\mathrm{V}_{\mathrm{p}}}{\mathrm{V}}}{\mathrm{w}} \\
\text { Jumlah gugus hidroksil }=\mathrm{N}_{\text {hidroksil }}-\mathrm{N}_{\text {karboksil }}-\text { Jumlah gugus lakton }
\end{gathered}
$$

Asumsi yang digunakan adalah (1) $\mathrm{NaHCO}_{3}$ menetralkan gugus karboksil, (2) $\mathrm{Na}_{2} \mathrm{CO}_{3}$ menetralkan gugus karboksil dan lakton, dan (3) $\mathrm{NaOH}$ menetralkan gugus karboksil, lakton dan hidroksil.

Dimana meq/g adalah satuan konsentrasi gugus aktif, $\mathrm{V}_{\mathrm{NaHCO}}$ adalah volume $\mathrm{NaHCO}_{3}, \mathrm{~N}_{\mathrm{NaHCO}}$ adalah normalitas larutan $\mathrm{NaHCO}_{3}, \mathrm{CHCl}_{\mathrm{HCl}}$ adalah konsentrasi larutan $\mathrm{HCl}, \mathrm{V}_{\mathrm{HCl}}$ adalah volume larutan $\mathrm{HCl}, \mathrm{C}_{\mathrm{NaOH}}$ adalah konsentrasi larutan $\mathrm{NaOH}, \mathrm{V}_{\mathrm{t}}$ adalah volume titrasi $(\mathrm{mL}), V_{p}$ adalah volume sampel yang direndam $(\mathrm{mL}), \mathrm{V}_{s}$ adalah volume sampel yang diambil $(\mathrm{mL}) . \mathrm{w}$ adalah berat sampel $(\mathrm{g})$, dan $\frac{\mathrm{V}_{\mathrm{p}}}{\mathrm{V}_{\mathrm{s}}}$ adalah faktor pengenceran.

\subsection{Analisis FTIR}

Analisis FTIR dilakukan pada biosorben batang jagung alami, biosorben batang jagung demineralisasi, dan biosorben batang jagung termodifikasi asam sitrat.

\subsection{Analisis Logam Ni dan Cu dengan AAS}

Preparasi limbah dilakukan dengan cara limbah logam sebanyak $50 \mathrm{~mL}$ dimasukkan dalam gelas kimia, kemudian diaduk hingga homogen. Limbah logam kemudian didestruksi dengan $10 \mathrm{~mL} \mathrm{HNO} 365 \%$ dan dipanaskan pada suhu $100^{\circ} \mathrm{C}$ hingga larutan bersisa $25 \mathrm{~mL}$, kemudian didinginkan dan dianalisis dengan AAS.

Adsorpsi limbah dilakukan dengan cara mengambil $100 \mathrm{~mL}$ limbah logam cair yang telah dipreparasi diinteraksikan dengan 0,5 gram biosorben batang jagung alami, batang jagung termineralisasi dan batang jagung termodifikasi asam sitrat (1,5 dan 2 M). Campuran adsorben dan limbah logam dishaker selama 30 menit dengan kecepatan $180 \mathrm{rpm}$. Kemudian larutan disaring dan diambil filtratnya. Filtrat yang dihasilkan didestruksi dengan $\mathrm{HNO}_{3} 65 \%$ dipanaskan pada suhu $100^{\circ} \mathrm{C}$ hingga larutan jernih dan dianalisis dengan AAS.

\section{Hasil dan Pembahasan}

\subsection{Penentuan Konsentrasi Gugus Aktif Biosorben Batang Jagung melalui Titrasi Boehm}

Tabel 1 menjelaskan bahwa pada semua variasi biosorben batang jagung mengandung gugus-gusus asam seperti karbosilik, hidroksilik dan laktonik. Modifikasi batang jagung menggunakan asam sitrat menghasilkan pembentukan hidroksil dan karboksilat, sementara tidak dijumpai pembentukan gugus lakton. Pada semua variasi konsentrasi asam sitrat, baik pada AM 1,5 M dan AM 2 M, pembentukan karboksil lebih besar dibanding pembentukan hidroksil. Hasil ini mirip hasil penelitian dari Leyva-Ramos dkk. [10] dan Wartelle \& Marshall [18]. 
Yulianti dkk. / ALCHEMY: JOURNAL OF CHEMISTRY, $7: 1$ (2019) 13-19

Tabel 1. Konsentrasi Gugus Aktif (Lakton, Hidroksil dan Karboksil)

\begin{tabular}{ccccc}
\hline \multirow{2}{*}{ Variasi Batang Jagung } & \multicolumn{4}{c}{ Total Situs (meq/g) } \\
\cline { 2 - 5 } & Asam & Lakton & Hidroksil & Karboksil \\
\hline BA & 1,8 & 0,55 & 0,45 & 0,80 \\
AKT & 0,7 & 0,10 & 0,35 & 0,25 \\
AM 1,5 M & 3,2 & 0,54 & 0,61 & 2,05 \\
AM 2 M & 2,7 & 0,45 & 0,60 & 1,65 \\
\hline
\end{tabular}

$\mathrm{M})$, dan batang jagung termodifikasi asam sitrat $2 \mathrm{M}(\mathrm{AM} 2 \mathrm{M})$.

Leyva-Ramos dkk. [10] dan Wing [19] menjelaskan mekanisme reaksi antara asam sitrat dan tongkol jagung dalam membentuk ester. Asam sitrat mengalami dehidrasi pada saat dipanaskan dan berubah menjadi anhidrat yang reaktif dan bereaksi dengan hidroksil dari selulosa dan lignin untuk membentuk ester. Setiap molekul asam sitrat berikatan dengan hidroksil dari tongkol jagung dalam reaksi esterifikasi. Selama proses modifikasi, setiap molekul asam sitrat yang bereaksi dengan sellulosa akan membentuk minimal 2 gugus karboksilat dan 1 gugus ester pada permukaan tongkol jagung [20]. Setelah proses modifikasi jumlah gugus asam total baik karboksilat dan hidroksilat meningkat hingga semua hidroksil selulosa bereaksi dengan asam sitrat, selanjutnya turun seiring dengan naiknya konsentrasi asam sitrat dalam larutan pengoksidasi. Hal ini disebabkan pada saat konsentrasi asam sitrat terus dinaikkan maka akan sangat banyak gugus karboksilat yang terbentuk pada permukaan biosorben. Akibatnya pada saat biosorben batang jagung direndam dalam air, terbentuklah ikatan silang diantara grup gugus karboksilat yang berlebih yang ada pada permukaan sehingga menurunkan jumlah gugus karbosilat yang masih bebas. Hasil tersebut sesuai dengan hasil karakterisasi gugus fungsi menggunakan FTIR yang disajikan pada Gambar 1.

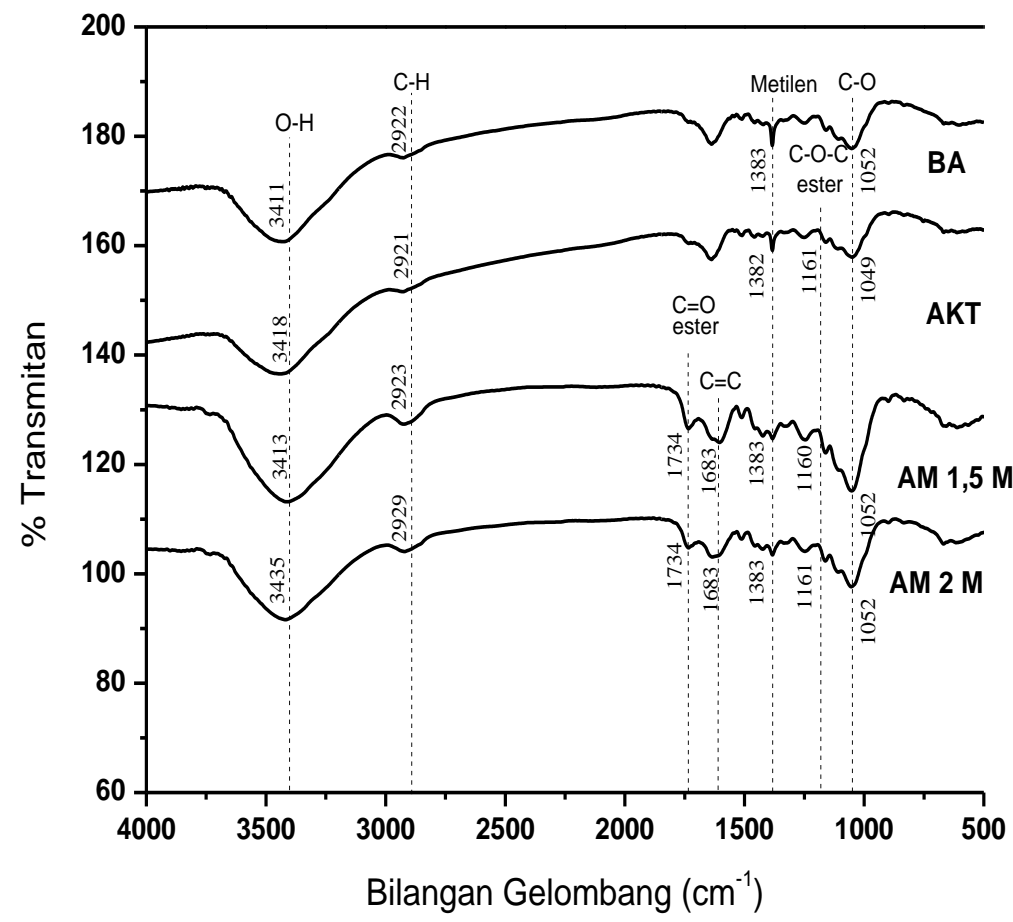

Gambar 1. Spektra FTIR biosorben batang jagung alami (BA), biosorben batang jagung teraktivasi (AKT), dan biosorben batang jagung termodifikasi asam sitrat 1,5 M (AM 1,5 M) dan termodifikasi $2 \mathrm{M}(\mathrm{AM} 2 \mathrm{M})$.

Spektra batang jagung alami (Gambar 1) terlihat adanya puncak serapan pada bilangan gelombang $3411-3435 \mathrm{~cm}^{-1}$ yang menunjukkan vibrasi ulur gugus $-\mathrm{OH}$ stretching band yang kuat dan lebar. Serapan kuat juga nampak pada bilangan gelombang 1049-1052 $\mathrm{cm}^{-1}$ mengindikasikan adanya C-O stretching band dan sebuah vibration band C-O-H diindikasikan oleh adanya 2 serapan (simetri dan asimetri model) pada serapan pada bilangan gelombang 1249 dan $1161 \mathrm{~cm}^{-1}$. Pita $C=C$ cincin aromatis muncul sebagai pasangan serapan pada 1683 dan $1425 \mathrm{~cm}^{-1}$. Ditemukan serapan pada bilangan gelombang $1734 \mathrm{~cm}^{-1}$ yang menunjukkan adanya serapan stretching gugus $\mathrm{C}=0$ ester. Serapan ini lemah pada batang jagung alami (BA) dan setelah aktivasi (AKT). Pada bilangan gelombang $2921-2929 \mathrm{~cm}^{-1}$ mengindikasikan adanya vibrasi ulur $\mathrm{C}-\mathrm{H}$ stretching band untuk $\mathrm{sp}^{3}$. Hal ini menunjukkan pada batang jagung alami tersusun dari alkohol, ester, aromatik dan eter. Hasil ini sangat mirip dengan hasil penelitian Wen dkk. [9] dan Leyva-Ramos dkk. [10]. 
Berdasarkan spektra pada BA, AM 1,5 M dan AM 2 M terlihat bahwa pasca modifikasi, spektra mengalami peningkatan intensitas. Hal ini menunjukkan meningkatnya jumlah grup gugus karbonil yaitu meningkatnya serapan pada streching C-O pada $1052 \mathrm{~cm}^{-1}$ dan stretching gugus $C=0$ ester pada $1734 \mathrm{~cm}^{-1}$. Kenaikan ini sangat signifikan yang menunjukkan bahwa modifikasi berjalan cukup baik. Tetapi jika dibandingkan spektra hasil modifikasi AM 1,5 M, spektra pada AM 2 M tidak mengalami peningkatan intensitas yg tajam. Hal ini mengindikasikan semua gugus hidroksil telah bereaksi dengan asam sitrat dan tidak ada lagi tambahan ester yang terbentuk.

Menurut Leyva-Ramos dkk. [10], hasil FTIR batang jangung setelah modifikasi mengalami penyusutan intensitas hingga $15 \%$, khususnya pada gugus karboksilat. Perubahan intensitas spektra yang signifikan yaitu pada gugus $\mathrm{C}=0$ ester dan $\mathrm{C}=\mathrm{C}$ aromatis. Hal ini menunjukkan perubahan polaritas dari munculnya senyawa baru yang terbentuk. Interaksi tersebut mengubah momen dipol pada ikatan rangkap yang mengindikasikan interaksi antara ikatan $\pi$ dan kation yaitu interaksi antara cincin aromatis dari lignin dan kation dari logam. Hasil ini sesuai dengan penelitian Wen dkk. [9], LeyvaRamos dkk. [10], dan Chen dkk. [11], interaksi ikatan $\pi$ dan kation sangat penting untuk mengadsorpsi ion logam berat.

\subsection{Pengaruh Modifikasi Batang Jagung pada Kapasitas Adsorpsi Limbah Logam}

Limbah cair laboratorium kimia dipisahkan dalam beberapa bagian berdasarkan kandungannya, salah satunya adalah limbah cair golongan logam berat. Limbah ini mengandung berbagai jenis logam sisa kegiatan riset maupun praktikum [21]. Limbah diolah menggunakan adsorben batang jagung tanpa dipisahkan jenis logamnya sehingga dalam sampel limbah cair yang digunakan dalam penelitian ini mengandung banyak jenis logam. Hasil adsorpsi batang jagung terhadap Ni dan Cu ditunjukkan pada Tabel 2.

Tabel 2. Konsentrasi Limbah Cair

\begin{tabular}{ccc}
\hline Sampel & Konsentrasi Ni (ppm) & Konsentrasi Cu (ppm) \\
\hline Limbah mula-mula & 63,05 & 241,30 \\
BA & 55,80 & 234,025 \\
AKT & 50,00 & 191,175 \\
AM 1,5 M & 44,65 & 100,05 \\
AM 2 M & 55,05 & 204,25 \\
\hline
\end{tabular}

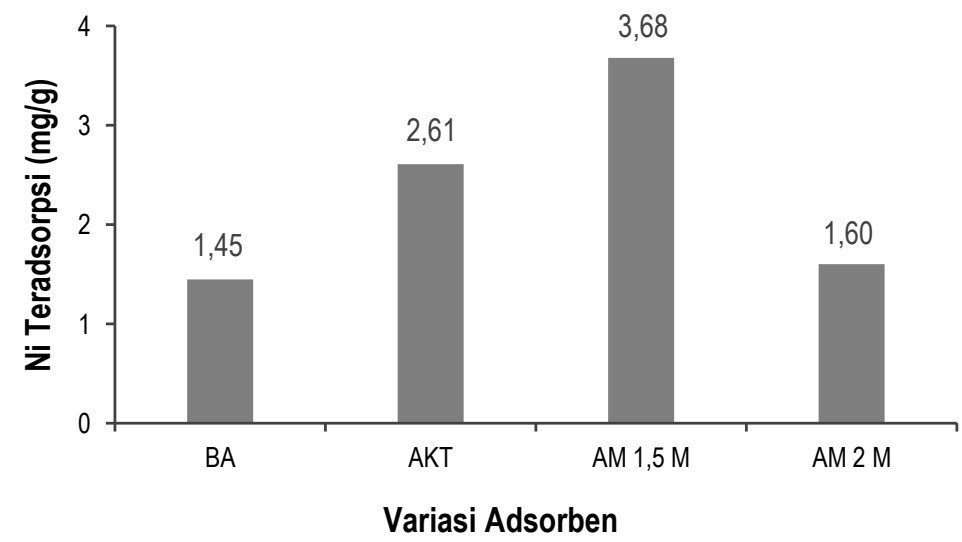

Gambar 2. Penurunan konsentrasi logam Ni pada limbah cair.

Gambar 2 dan 3 menunjukkan peningkatan jumlah logam yang teradsorpsi pada batang jagung setelah perlakuan demineralisasi $\mathrm{HCl}$ maupun pada batang jagung setelah demineralisasi dan dilanjut dengan modifikasi menggunakan asam sitrat. Adsorpsi ion Cu jauh lebih tinggi dibanding adsorpsi terhadap Ni. Hal ini menunjukkan terjadinya persaingan antar logam pada air limbah. Tabel 2 menunjukkan tingginya konsentrasi Ni dan $\mathrm{Cu}$ dalam limbah cair dengan konsentrasi $\mathrm{Ni}$ dalam air limbah sebesar 63,05 ppm, nilai ini jauh lebih kecil dibanding konsentrasi Cu sebesar 241,3 ppm. Hal ini mengakibatkan peluang $\mathrm{Cu}$ teradsorpsi jauh lebih besar dibandingkan $\mathrm{Ni}$. 


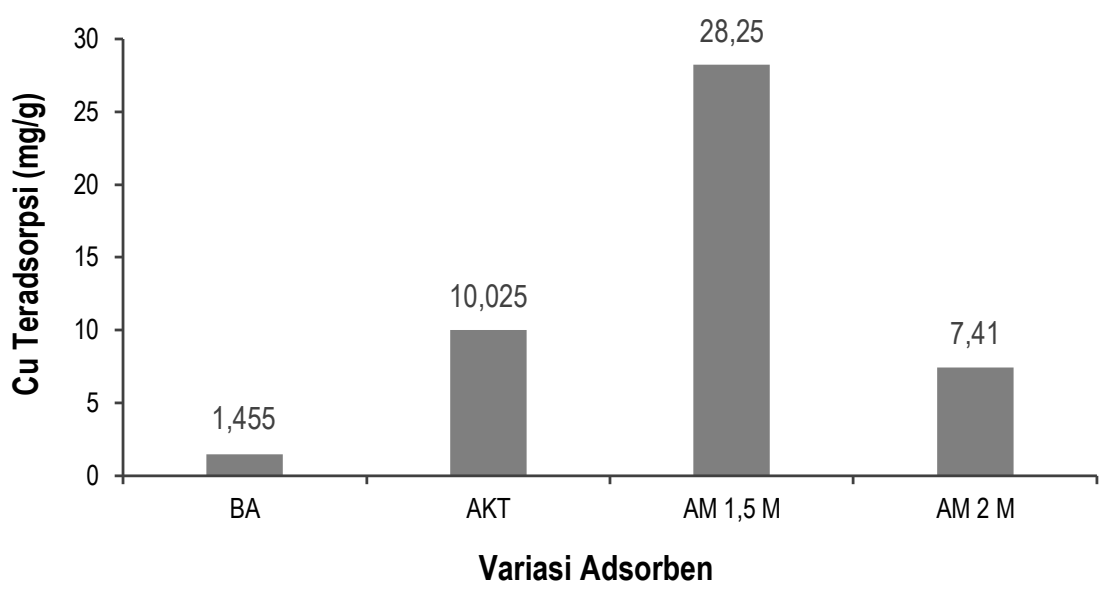

Gambar 3. Penurunan konsentrasi logam Cu pada limbah cair.

Kapasitas adsorpsi semua variasi modifikasi asam sitrat lebih besar dibandingkan batang jagung alami, hal ini menunjukkan suksesnya modifikasi asam sitrat pada batang jagung. Namun, seperti yang ditunjukkan pada Gambar 4, adsorpsi logam pada AM 1,5 M lebih tinggi dibanding AM $2 \mathrm{M}$ karena gugus fungsi karboksilat bebas yang mampu berikatan dengan logam pada permukaan batang jagung AM 1,5 M lebih banyak dibanding AM $2 \mathrm{M}$. Hal ini membuktikan pada saat konsentrasi asam sitrat dinaikkan AM $2 \mathrm{M}$, terjadi jumlah grup karboksilat di permukaan meningkat, meruah dan berpotensi memicu terjadinya ikatan silang pada grup karboksilat yang sudah terikat di permukaan batang jagung. Hal ini menghalangi terikatnya karboksilat dengan ion logam sehingga menurunkan kemampuan adsorpsi.

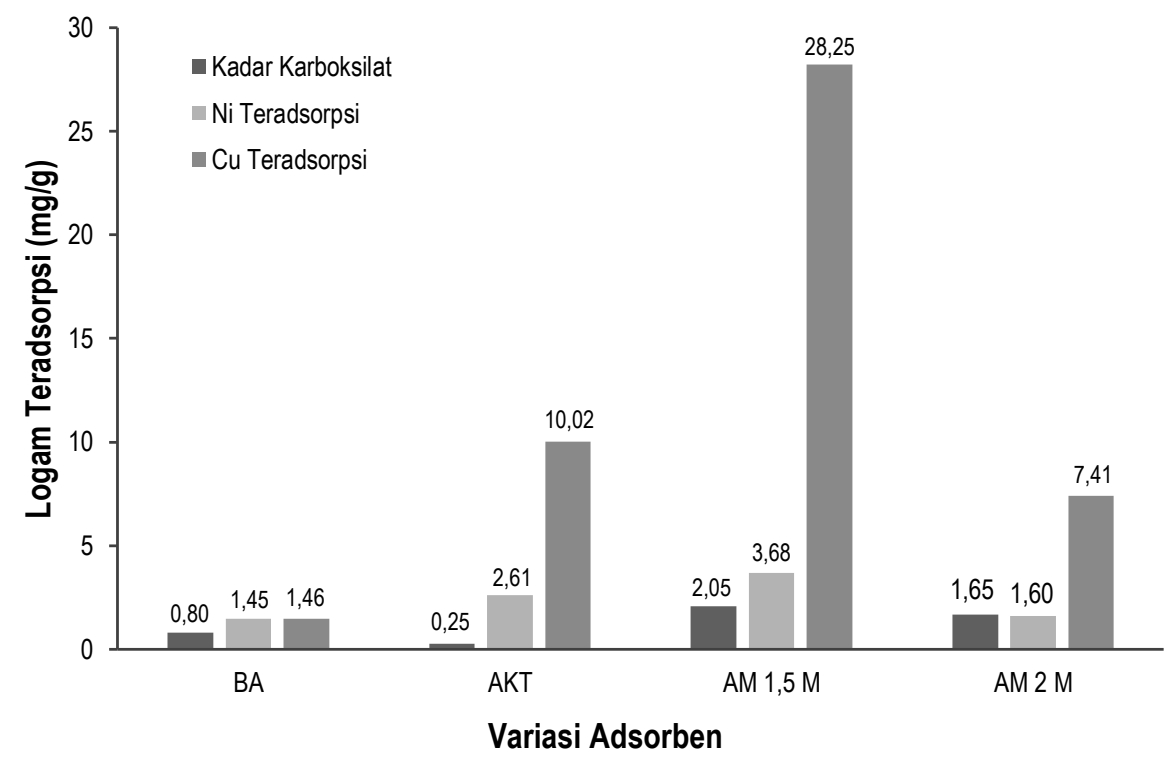

Gambar 4. Hubungan kadar karboksilat dan banyaknya logam yang teradsorpsi

\section{Kesimpulan}

Berdasarkan hasil penelitian dapat disimpulkan bahwa modifikasi asam sitrat pada batang jagung dapat meningkatkan kemampuan adsorpsi batang jagung. Selama modifikasi gugus karboksilat terbentuk lebih banyak dibandingkan terbentuknya gugus hidroksil, sedangkan gugus lakton tidak terbentuk. Batang jagung termodifikasi menghasilkan gugus ester yang ditunjukkan munculnya serapan baru pada bilangan gelombang $1733-1734 \mathrm{~cm}^{-1}$. Total gugus asam pada modifikasi asam sitrat 1,5 M lebih baik dibanding modifikasi asam sitrat $2 \mathrm{M}$. Adsorben batang jagung termodifikasi 1,5 M mampu menyerap ion logam Ni dan Cu pada limbah cair masing-masing mencapai 3,68 dan 28,25 $\mathrm{mg} / \mathrm{g}$. 


\section{Daftar Pustaka}

[1] V. Krstić, T. Urošević, \& B. Pešovski, "A Review on Adsorbents for Treatment of Water and Wastewaters Containing Copper lons," Chemical Engineering Science, vol. 192, pp. 273-287, 2018.

[2] L. Zheng, Z. Dang, X. Yi, \& H. Zhang, "Equilibrium and Kinetic Studies of Adsorption of Cd(II) from Aqueous Solution using Modified Corn Stalk," Journal of Hazardous Materials, vol. 176, no. 1-3, pp. 650-656, 2010.

[3] S. Mishra, P. S. Kharkar, \& A. M. Pethe, "Biomass and Waste Materials as Potential Sources of Nanocrystalline Cellulose: Comparative Review of Preparation Methods (2016 - Till Date)," Carbohydrate Polymers, vol. 207, pp. 418-427, 2019.

[4] R. Z. Khoo, W. S. Chow, \& H. Ismail, "Sugarcane Bagasse Fiber and Its Cellulose Nanocrystals for Polymer Reinforcement and Heavy Metal Adsorbent: A Review," Cellulose, vol. 25, no. 8, pp. 4303-4330, 2018.

[5] M. Ariani, "Dinamika Konsumsi Beras, Jagung dan Kedelai Mendukung Swasembada Pangan," Badan Penelitian dan Pengembangan Pertanian. 2015. [Online]. Tersedia: http://www.litbang.pertanian.go.id/buku/swasembada/BAB-IV3.pdf. [Diakses: 1 Maret 2019].

[6] Y. T. Wang, H. Chen, D. J. Wang, L. J. Bai, H. Xu, \& W. X. Wang, "Preparation of Corn Stalk-based Adsorbents and Their Specific Application in Metal Ions Adsorption," Chemical Papers, vol. 70, no. 9, pp. 1171-1184, 2016.

[7] N. Rehman, M. I. G. de Miranda, S. M. L. Rosa, D. M. Pimentel, S. M. B. Nachtigall, \& C. I. D. Bica, "Cellulose and Nanocellulose from Maize Straw: An Insight on the Crystal Properties," Journal of Polymers and the Environment, vol. 22, no. 2, pp. 252-259, 2014.

[8] T. Wang, J. Yin, \& Z. Zheng, "Effects of Chemical Inhomogeneity of Corn Stalk on Solvolysis Liquefaction," Carbohydrate Polymers, vol. 87, no. 4, pp. 2638-2641, 2012.

[9] X. Wen, C. Yan, N. Sun, T. Luo, S. Zhou, \& W. Luo, "A Biomass Cationic Adsorbent Prepared from Corn Stalk: LowCost Material and High Adsorption Capacity," Journal of Polymers and the Environment, vol. 26, no. 4, pp. 16421651, 2018.

[10] R. Leyva-Ramos, L. E. Landin-Rodriguez, S. Leyva-Ramos, \& N. A. Medellin-Castillo, "Modification of Corncob with Citric Acid to Enhance Its Capacity for Adsorbing Cadmium(II) from Water Solution," Chemical Engineering Journal, vol. 180, pp. 113-120, 2012.

[11] S. Chen, Q. Yue, B. Gao, Q. Li, \& X. Xu, "Removal of $\operatorname{Cr}(\mathrm{VI})$ from Aqueous Solution using Modified Corn Stalks: Characteristic, Equilibrium, Kinetic and Thermodynamic Study," Chemical Engineering Journal, vol. 168, no. 2, pp. 909-917, 2011.

[12] L. Zheng, Z. Dang, C. Zhu, X. Yi, H. Zhang, \& C. Liu, "Removal of Cadmium(II) from Aqueous Solution by Corn Stalk Graft Copolymers," Bioresource Technology, vol. 101, no. 15, pp. 5820-5826, 2010.

[13] E. Yulianti \& I. Royana, "Pemanfaatan Biosorben Batang Jagung Teraktivasi Asam Nitrat dan Asam Sulfat untuk Penurunan Angka Peroksida-Asam Lemak Bebas Minyak Goreng Bekas," ALCHEMY: Journal of Chemistry, vol. 5 , no. 1, pp. 9-18, 2018.

[14] S. Vafakhah, M. E. Bahrololoom, R. Bazarganlari, \& M. Saeedikhani, "Removal of Copper lons from Electroplating Effluent Solutions with Native Corn Cob and Corn Stalk and Chemically Modified Corn Stalk," Journal of Environmental Chemical Engineering, vol. 2, no. 1, pp. 356-361, 2014.

[15] J. C. Igwe \& A. A. Abia, "A Bioseparation Process for Removing Heavy Metals from Waste Water using Biosorbents," African Journal of Biotechnology, vol. 5, no. 12, pp. 1167-1179, 2006.

[16] H. P. Boehm, "Some Aspects of the Surface Chemistry of Carbon Blacks and Other Carbons," Carbon, vol. 32, no. 5, pp. 759-769, 1994.

[17] S. L. Goertzen, K. D. Thériault, A. M. Oickle, A. C. Tarasuk, \& H. A. Andreas, "Standardization of the Boehm Titration. Part I. $\mathrm{CO}_{2}$ Expulsion and Endpoint Determination," Carbon, vol. 48, no. 4, pp. 1252-1261, 2010.

[18] L. H. Wartelle \& W. E. Marshall, "Citric Acid Modified Agricultural By-products as Copper lon Adsorbents," Advances in Environmental Research, vol. 4, no. 1, pp. 1-7, 2000.

[19] R. E. Wing, "Corn Fiber Citrate: Preparation and lon-exchange Properties," Industrial Crops and Products, vol. 5, no. 4, pp. 301-305, 1996.

[20] T. Vaughan, C. W. Seo, \& W. E. Marshall, "Removal of Selected Metal lons from Aqueous Solution using Modified Corncobs," Bioresource Technology, vol. 78, no. 2, pp. 133-139, 2001.

[21] R. Darmawan, S. N. Khalifah, E. Yulianti, \& D. Prasetyoko, "Sintesis dan Karakterisasi Zeolit NaA dari Kaolin dan Metakaolin sebagai Adsorben Logam Fe dan Pb pada Limbah Logam Laboratorium," Skripsi, Universitas Islam Negeri Maulana Malik Ibrahim, Malang, 2017. 